\title{
Chromosomal aberrations in peripheral lymphocytes from male native miners working in the Peruvian Andes
}

\author{
Sergio R. Santa Maria*, Margarita Arana and Oswaldo Ramirez \\ Unidad de Biología Integrativa, Departamento de Ciencias Biológicas y Fisiológicas, Facultad de Ciencias \\ y Filosofia, Universidad Peruana Cayetano Heredia, Lima, Peru.
}

\begin{abstract}
We analyzed the frequency of chromosomal aberrations in peripheral lymphocytes from underground miners from the Casapalca $(n=8$, mean age $=45 y$, range $=36$ y to $55 y)$ and Bellavista $(n=8$, mean age $=28 y$, range 23 y to 34 y) high-altitude mining camps in the Peruvian Andes. This population was occupationally exposed to heavy metals such as lead and zinc as well as diesel emission particles, organic solvents and mine dust. The control groups consisted of individuals from a high altitude farming community in the Peruvian village of Tinco $(n=8$, mean age $=37 \mathrm{y}$, range $=25 \mathrm{y}$ to $52 \mathrm{y})$ and the sea level city of Lima $(n=14$, mean age $=26 \mathrm{y}$, range $=20 \mathrm{y}$ to $35 \mathrm{y})$. All individuals were male native Peruvians. A significantly higher incidence $(1.88 \%, p<0.05)$ of chromosomal aberrations (chromatid deletions and breaks, chromosome breaks and acentric fragments) were detected in lymphocytes from miners at the Casapalca camp as compared to miners from the Bellavista camp $(0.5 \%$, chromatid deletions and acentric fragments only) and the Lima sea level ( $0.07 \%$, chromatid deletions only) and Tinco high altitude (no aberrations) controls. These results suggest that male native Peruvians occupationally exposed to underground mining activity have an increased frequency of chromosomal aberrations, which could be related to both age and exposure time. The increased chromosomal damage observed in the mining populations studied may be attributable to the complex mixture of genotoxic agents to which the miners may have been exposed.
\end{abstract}

Key words: chromosomal aberrations, high altitude, mutagenesis, Peruvian Andes, underground miners.

Received: August 9, 2006; Accepted: January 31, 2007.

Chromosomal aberrations in human peripheral lymphocytes are well-established biomarkers of exposure to occupational or environmental genotoxic agents, cytogenetic analyses of lymphocytes from populations occupationally exposed to such agents having shown increased chromosomal aberration frequencies (Deknudt et al., 1973; Bauchinger et al., 1976; Lazutka et al., 1999; Topaktas et al., 2002). Underground miners are particularly exposed to complex mixtures of chemicals (e.g., heavy metals, diesel emission particles and dust), many of which are known mutagens (Johnson, 1998; Keshava and Ong, 1999; Rojas et al., 1999; Scheepers et al., 2002; Wolf et al., 2004; Donbak et al., 2005). Peruvian miners normally work at high altitude without any appropriate protective equipment, with chronic mountain sickness (excessive erythrocytosis caused by long term exposure to high altitude), silicosis and

Send correspondence to Oswaldo E. Ramirez. Facultad de Ciencias y Filosofía, Universidad Peruana Cayetano Heredia, Av. Honorio Delgado 430, Urb. Ingeniería, San Martín de Porres, Lima, Perú. E-mail: oramirez@upch.edu.pe.

*Present address: University of Texas Medical Branch, 301 University Boulevard, 77555-1061 Galveston, Texas, U.S.A. E-mail: srsantam@utmb.edu tuberculoses having frequently been reported in such workers (Paitán, 1965; León-Velarde and Arregui, 1992).

Despite the fact that there are large numbers of underground miners in Peru there have been no published studies regarding the occupational exposure of these workers to genotoxic agents, one reason being the very difficult access to blood samples from these workers who are mainly native Andeans known for their aversion to blood extraction procedures.

We report the results of the cytogenetic analysis of chromosomal aberrations in peripheral blood lymphocytes from a group of native Peruvian miners working at high altitude in the Peruvian Andes as compared to native Peruvian farmers from high altitude and sea level individuals.

Four groups of native Peruvian males were studied: underground miners ( $\mathrm{n}=8$, mean age $=45 \mathrm{y}$, range $=36 \mathrm{y}$ to $55 \mathrm{y}$; average exposure time $=234$ months) at the Casapalca mining camp (11 $30^{\prime} \mathrm{S}, 76^{\circ} 10^{\prime} \mathrm{W}, 4100 \mathrm{~m}$ altitude); underground miners $(\mathrm{n}=8$, mean age $=28 \mathrm{y}$, range $23 \mathrm{y}$ to $34 \mathrm{y}$; average exposure time $=31.5$ months) at the Bellavista mining camp ( $11^{\circ} 41^{\prime} \mathrm{S}, 76^{\circ} 15^{\prime} \mathrm{W}, 3800 \mathrm{~m}$ altitude); high altitude farmers $(\mathrm{n}=8$, mean age $=37 \mathrm{y}$, range $=25 \mathrm{y}$ to 
$52 \mathrm{y})$ from the high altitude village of Tinco $\left(9^{\circ} 33^{\prime} \mathrm{S}\right.$, $77^{\circ} 40^{\prime}$ W, $3550 \mathrm{~m}$ altitude, Huaraz Province, Ancash Department); and urban individuals $(\mathrm{n}=14$, mean age $=26 \mathrm{y}$, range $=20 \mathrm{y}$ to $35 \mathrm{y}$ ) from the sea level city of Lima. The time of exposure to mining activity varied significantly between both groups, principally because the mining company prefers to place young workers in the Bellavista camp. Casapalca and Bellavista mining camps are both located in Huarochiri Province in the Department of Lima and are separated by less than $20 \mathrm{~km}$; miners from both camps work at the same location. In order of importance, the major minerals extracted from this mine are lead, silver, zinc and copper ores. Although personal protective equipment such as overalls and safety boots, helmets and masks are normally used they are often old and/or in bad condition.

All participants gave informed consent and blood samples were collected and further manipulated in accordance with the recommendations of the Ethics Committee of the Universidad Peruana Cayetano Heredia. When the blood samples were collected each individual also completed a personal history questionnaire on standard demographic questions such as age and place of birth as well as lifestyle and health status factors including employment history, prior occupational exposure to other chemicals and/or radiation, time of exposure to mining activities, drug and tobacco usage and eating habits. According to the questionnaires all the participants were healthy and had not been regularly using prescription medicines nor been exposed to radiation and/or chemicals outside their work environment during the month prior to sampling. Occupational exposure to radiation and/or radiation dose could not be determined because we did not have access to the mine. Only two subjects from Casapalca, two from Bellavista, three from the Tinco high altitude control and four from the Lima sea level control were occasional smokers (less than six cigarettes each week).

Blood samples were collected by venipuncture in sterile heparinized and coded tubes. Lymphocytes were cultured for $72 \mathrm{~h}$ at $37^{\circ} \mathrm{C}$ (Moorhead et al., 1960). Wholeblood cultures were prepared within $24 \mathrm{~h}$ of collection using RPMI-1640 culture medium (BioWhittaker) enriched with $4 \%(\mathrm{v} / \mathrm{v})$ fetal bovine serum (Sigma), $2 \%(\mathrm{w} / \mathrm{v}) \mathrm{L}$-glutamine (Gibco BRL) and 2\% (w/v) phytohemagglutinin-M (Gibco BRL), $16 \mu \mathrm{g} \mathrm{mL}^{-1}$ colchicine (Sigma) being added 45 to $50 \mathrm{~min}$ before harvesting. The cells were collected by centrifugation, resuspended briefly in pre-warmed hypotonic $0.075 \mathrm{M} \mathrm{KCl}$ and fixed twice in acetic acid/methanol $(1: 3, \mathrm{v} / \mathrm{v})$. The preparations were air-dried at room temperature and stained with $2.5 \%(\mathrm{w} / \mathrm{v})$ Giemsa in methanol.

The evaluation of chromosomal aberrations was performed following the IPCS guidelines for the monitoring of genotoxic effects of carcinogens in humans (Albertini et al., 2000). All slides were coded, mixed and analyzed blind, with 100 well-spread metaphases being screened for each subject. Achromatic lesions (gaps) were not elevated as true chromosomal aberrations (Mace et al., 1978; Savage, 2004). Chromosomal aberration frequency differences between groups were analyzed using a small sample test of significance for a Poisson distribution (Rao and Chakravarti, 1956) and the Pearson coefficient of correlation to analyze the association between chromosomal aberration frequency and both exposure time and age.

Data on the number and frequency of chromosomal aberrations for each study group are presented in Table 1. A significantly higher incidence $(1.88 \%, \mathrm{p}<0.05)$ of chromosomal aberrations (chromatid deletions and breaks, chromosome breaks and acentric fragments) were detected in lymphocytes from miners at the Casapalca camp as compared to miners from the Bellavista camp $(0.5 \%$, chromatid deletions and acentric fragments only) and the Lima sea level $(0.07 \%$, chromatid deletions only) and Tinco high altitude (no aberrations) controls. The most frequent aberrations encountered in the miner populations were chromatid deletions (Casapalca miners 1\%, Bellavista miners $0.13 \%$ ) and acentric fragments (Casapalca miners $0.5 \%$, Bellavista miners $0.38 \%$ ). The Pearson correlation coefficient be-

Table 1 - Frequencies of chromosomal aberrations in peripheral lymphocytes from miners working in high altitude Peruvian mines and controls consisting of high altitude farmers from the Peruvian village of Tinco and sea level urban individuals from Lima, Peru. All individuals were male native Peruvians. For each individual we screened 100 well-spread metaphases. The percentages represent the number of chromosomal aberrations respective to the total number of cells scored per group.

\begin{tabular}{|c|c|c|c|c|c|c|c|c|c|}
\hline \multirow{3}{*}{$\begin{array}{l}\text { Study group } \\
\text { ( } \mathrm{n}=\text { number of } \\
\text { individuals) }\end{array}$} & \multicolumn{8}{|c|}{ Type, total number and percentage of chromosomal aberrations } & \multirow{3}{*}{$\begin{array}{c}\text { Total aberrations } \\
\text { per group (\%) }\end{array}$} \\
\hline & \multicolumn{2}{|c|}{ Chromatid deletions } & \multicolumn{2}{|c|}{ Chromatid breaks } & \multicolumn{2}{|c|}{ Chromosome breaks } & \multicolumn{2}{|c|}{ Acentric fragments } & \\
\hline & Number & $\%$ & Number & $\%$ & Number & $\%$ & Number & $\%$ & \\
\hline Casapalca miners $(\mathrm{n}=8)$ & 8 & 1.00 & 2 & 0.25 & 1 & 0.13 & 4 & 0.50 & $15(1.88)^{\mathrm{a}, \mathrm{b}}$ \\
\hline Bellavista miners $(\mathrm{n}=8)$ & 1 & 0.13 & 0 & 0 & 0 & 0 & 3 & 0.38 & $4(0.50)^{\mathrm{c}}$ \\
\hline Sea level controls $(n=14)$ & 1 & 0.07 & 0 & 0 & 0 & 0 & 0 & 0 & $1(0.07)^{\mathrm{b}}$ \\
\hline High altitude controls $(\mathrm{n}=8)$ & 0 & 0 & 0 & 0 & 0 & 0 & 0 & 0 & 0 \\
\hline
\end{tabular}

${ }^{a}$ Significantly different from both the high altitude and sea level controls (Poisson distribution test, $\mathrm{p}<0.05$ )

${ }^{\mathrm{b}}$ Significantly different from the Bellavista mine workers (Poisson distribution test, $\mathrm{p}<0.05$ ).

${ }^{\mathrm{c}}$ Not significant compared to the high altitude controls (Poisson distribution test, $\mathrm{p}=0.0625$ ). 
tween age and exposure time $(r=0.905)$ was significant $(\mathrm{p}<0.001, \mathrm{n}=16)$ for the miners, indicating that these variables were not independent. Furthermore, the coefficient of determination between the frequency of chromosomal aberrations and age was 0.26 while for exposure time it was 0.21 , indicating a close relationship between the increase in the frequency of chromosomal aberrations and age (and exposure time) which has been reported in previous studies (Sarto et al., 1985; Migliori et al., 1991). Since age and exposure time were not independent from each other we were unable to separate their effects. However, a significant increase in chromatid-type aberrations has been correlated with duration of exposure and age by other authors. For example, Donbak et al. (2005) reported that coal miners showed both sisters chromatid exchanges (SCEs) and chromatid- and chromosomal-type aberrations which were significantly enhanced as the number of years of exposure increased. On the other hand, Ganguly (1993) found that as the age of healthy donors increased mitotic index decreased linearly and there was a linear increase in chromosomal abnormalities and damaged cells. However, although it has been accepted that chromatid-type aberrations tend to be rapidly lost as a result of cell division (Bender et al., 1988), our results suggest that factors related with aging could delay such losses.

The most plausible explanation for the non-significant difference in the frequency of chromosomal aberrations between Bellavista miners and the high altitude controls is the relatively short time of exposure of the Bellavista miners to mining activity. The genotoxic effects of UV radiation at high altitudes (Keshava and Ong, 1999; Tomatis, 2000) and the general malnutrition of Andean populations (Picón-Reátegui, 1976) did not seem to increase the frequency of chromosomal aberrations in the Bellavista miners. Furthermore, there was no statistically significant increase in the chromosomal aberration frequency of the high altitude Tinco farmers (analogous to the Bellavista miners) as compared to individuals from the sea level city of Lima.

Although our sample populations were small, the percentage of aberrant cells in lymphocytes of the Casapalca miners was very high as compared to the controls and it is reasonable to assume that the increased frequency of chromosomal aberrations was a primary consequence of the occupational exposure of the Casapalca miners to complex mixtures of genotoxic compounds such as heavy metals, diesel emission particles, organic solvents and mine dust (Keshava and Ong, 1999; Scheepers et al., 2002; Wolf et al., 2004; Donbak et al., 2005).

Previous studies in healthy populations have reported normal ranges for different types of chromosomal aberrations but both known and unknown factors impede the establishment of a universal baseline (Galloway et al., 1986; Bender et al., 1988; Stephan and Press1, 1999). Diverse factors can cause variation in the background level of chromo- somal aberrations, including cell-culture conditions (medium, incubation time) and population variables such as dietary habits, location and environmental factors such as air pollution (Milillo et al., 1996; Stephan and Pressl, 1999). At least three factors could be related to the low frequency of chromosomal aberrations found in our control groups (Table 1): small sample size, scoring differences and the location of the population. The low frequencies in our control groups could indicate that the chromosomal aberration frequency was underestimated for both the miners and control populations, probably due to bias introduced by the small number of individuals studied and the rarity of chromosomal aberrations in the controls. Scoring differences could be another factor involved in the differences between the chromosomal aberration frequency found in our controls and those reported for controls in previous studies (Galloway et al., 1986; Bender et al., 1988; Stephan and Pressl, 1999). In addition, several studies have shown that exposure to environmental pollution can modify the baseline levels of chromosomal aberrations (Lakhanisky et al., 1993; Klemans et al., 1995) and, as a consequence, a low frequency of chromosomal aberrations has previously been reported in rural populations (Milillo et al., 1996).

Underground miners are often exposed to complex mixtures of chemical agents and physical factors, making it very difficult to determine the precise cause of the increased chromosomal damage observed in the Casapalca miners investigated by us. Moreover, studies such as this are frequently complicated by confounding factors such as age, life-style, smoking and other habits. In the Andean mine workers, we show a positive association between the frequency of chromosomal aberrations and both time of exposure and age.

The results of cytogenetic biomonitoring are considered to be a valuable index of exposure to genotoxic carcinogens (Hagmar et al., 2004), although the only cytogenetic biomarker validated as an estimator of cancer risk is the classical metaphase analysis for measurement of chromosomal aberrations (Bonassi et al., 2000; Fenech, 2002; Smerhovsky et al., 2002; Hagmar et al., 2004). Although the increased frequency of chromosomal aberrations reported for our Casapalca Peruvian miner population could be associated with an increased risk of cancer, more accurate cytogenetic and epidemiological studies are needed to confirm our results. This study constitutes the first published record of occupational exposure to genotoxic agents in an Andean population.

\section{Acknowledgments}

We are grateful to P. Herrera of the Laboratorios de Investigación y Desarrollo of the Universidad Peruana Cayetano Heredia for allowing us to use her culture facilities. This investigation was supported by the Universidad Peruana Cayetano Heredia "Barbara Ann Kotowski de Tejada" Award 2001. 


\section{References}

Albertini RJ, Anderson D, Douglas GR, Hagmar L, Hemminki K, Merlo F, Natarajan AT, Norppa H, Shuker DE, Tice R, et al. (2000) IPCS guidelines for the monitoring of genotoxic effects of carcinogens in humans. Mutat Res 463:111-172.

Bauchinger M, Schmid E, Einbrodt HJ and Dresp J (1976) Chromosome aberrations in lymphocytes after occupational exposure to lead and cadmium. Mutat Res 40:57-62.

Bender MA, Preston RJ, Leonard RC, Pyatt BE, Gooch PC and Shelby MD (1988) Chromosomal aberration and sisterchromatid exchange frequencies in peripheral lymphocytes of a large human population sample. Mutat Res 204:421433.

Bonassi S, Hagmar L, Strömberg U, Montagud AH, Tinnerberg H, Forni A, Heikkilä P, Wanders S, Wilhardt P, Hansteen IL, et al. (2000) Chromosomal aberrations in lymphocytes predict human cancer independently of exposure to carcinogens. Cancer Res 60:1619-1625.

Deknudt G, Léonard A and Ivanov B (1973) Chromosome aberrations observed in male workers occupationally exposed to lead. Environ Physiol Biochem 3:132-138.

Donbak L, Rencuzogullari E, Yavuz A and Topaktas M (2005) The genotoxic risk of underground coal miners from Turkey. Mutat Res 588:82-87.

Fenech M (2002) Biomarkers of genetic damage for cancer epidemiology. Toxicology 181:411-416.

Galloway SM, Berry PK, Nichols WW, Wolman SR, Soper KA, Stolley PD and Archer P (1986) Chromosome aberrations in individuals occupationally exposed to ethylene oxide, and in a large control population. Mutat Res 170:55-74.

Ganguly BB (1993) Cell division, chromosomal damage and micronucleus formation in peripheral lymphocytes of healthy donors: Related to donor's age. Mutat Res 295:135-148.

Hagmar L, Strömbergu, Bonassi S, Hansteen IL, Knudsen LE, Lindholm C and Norppa H (2004) Impact of types of lymphocyte chromosomal aberrations on human cancer risk: Results from Nordic and Italian cohorts. Cancer Res 64:2258-2263.

Johnson FM (1998) The genetic effects of environmental lead. Mutat Res 410:123-140.

Keshava N and Ong T (1999) Occupational exposure to genotoxic agents. Mutat Res 437:175-194.

Klemans W, Vleminckx C, Schriewer L, Joris I, Lijsen N, Maes A, Ottogali M, Pays A, Planard C, Rigaux G, et al. (1995) Cytogenetic biomonitoring of a population of children allegedly exposed to environmental pollutants. Phase 2: Results of a three-year longitudinal study. Mutat Res 342:147-156.

Lakhanisky T, Bazzoni D, Jadot P, Joris I, Laurent C, Ottogali M, Pays A, Planard C, Ros Y and Vleminckx C (1993) Cytogenetic monitoring of a village population potentially exposed to a low level of environmental pollutants. Phase 1: SCE analysis. Mutat Res 319:317-323.

Lazutka JR, Lekevièius R, Dedonyte V, Maciulevièiûte-Gervers L, Mierauskiene J, Rudaitiene S and Slapsyte G (1999) Chromosomal aberrations and sister-chromatid exchanges in Lithuanian populations: Effects of occupational and environmental exposures. Mutat Res 445:225-239.
León-Velarde F and Arregui A (1992) Ocupación: Perforista, y el riesgo de mal de montaña crónico. Rev Med Hered 3:41-42.

Mace ML, Daskaly and Wray W (1978) Scanning electron microscopy of chromosome aberrations. Mutat Res 52:199206.

Migliori L, Parrini M, Sbrana I, Biagini C, Battaglia A and Lobrieno N (1991) Micronucleated lymphocytes in people occupationally exposed to potential environmental contaminants: The age effect. Mutat Res 256:13-20.

Milillo CP, Gemignani F, Sbrana I, Carrozzi L, Viegi G and Barale R (1996) Chromosome aberrations in humans in relation to site of residence. Mutat Res 360:173-179.

Moorhead PS, Nowell PC, Mellman WJ, Battips DM and Hungerford DA (1960) Chromosome preparations of leukocytes cultured from human peripheral blood. Exp Cell Res 20:613-616.

Paitán J (1965) Tuberculosis pulmonar y silicosis en Cerro de Pasco: Aspectos médicos sociales. Rev Cuerpo Med 4:447455.

Picon-Reategui E (1976) Nutrition. In: Baker PT and Little MA (eds) Man in the Andes: A Multidisciplinary Study of HighAltitude Quechua. Dowden, Hutchinson \& Ross, Stroudsburg, pp 208-236.

Rao CR and Chakravarti IM (1956) Some small sample tests of significance for a Poisson distribution. Biometrics 12:264282.

Rojas E, Herrera LA, Poirier LA and Ostrosky-Wegman P (1999) Are metals dietary carcinogens? Mutat Res 443:157-181.

Sarto F, Faccioli MC, Cominato I and Levis AG (1985) Aging and smoking increase the frequency of sister-chromatid exchanges (SCE) in man. Mutat Res 144:183-187.

Savage JRK (2004) On the nature of visible chromosomal gaps and breaks. Cytogenet Genome Res 104:46-55.

Scheepers PT, Coggon D, Knudsen LE, Anzion R, Autrup H, Bogovski S, Bos RP, Dahmann D, Farmer P, Martin EA, et al. (2002) Biomarkers for occupational diesel exhaust exposure monitoring (biomodem) - A study in underground mining. Toxicol Lett 134:305-317.

Smerhovsky Z, Landa K, Rössner P, Juzova D, Brabec M, Zudova Z, Hola N, Zarska H and Nevsimalova E (2002) Increased risk of cancer in radon-exposed miners with elevated frequency of chromosomal aberrations. Mutat Res 514:165176.

Stephan G and Pressl S (1999) Chromosomal aberrations in peripheral lymphocytes from healthy subjects as detected in first cell division. Mutat Res 446:231-237.

Tomatis L (2000) The identification of human carcinogens and primary prevention of cancer. Mutat Res 462:407-421.

Topaktas M, Rencüzodullari E, Yla HB and Kayraldiz A (2002) Chromosome aberration and sister chromatid exchange in workers of the iron and steel factory of Yskenderun, Turkey. Teratog Carcinog Mutagen 22:411-423.

Wolf G, Arndt D, Kotschy-Lang N and Obe G (2004) Chromosomal aberrations in uranium and coal miners. Int J Radiat Biol 80:147-153.

Associate Editor: Catarina S. Takahashi 